\title{
TD-LTE 游牧中继及回传链路设计与测试
}

\author{
郭志恒*, 钱雨, 范锐, 王亥 \\ 爱立信 (中国) 通信有限公司, 北京 100102 \\ * 通信作者. E-mail: zhiheng.guo@ericsson.com \\ 收稿日期: 2012-04-19; 接受日期: 2012-07-29
}

\begin{abstract}
摘要 TD-LTE 中继作为无线蜂窝网络中的一个节点, 具有提升小区边缘用户吞吐量, 扩展网络覆 盖以及提供高速无线回传链路的能力. 爱立信作为 TD-LTE 中继技术的领导者开发了 “TD-LTE 游 牧中继” 带内中继试验系统, 接入链路完全兼容 3GPP TD-LTE R8 协议, 使 TD-LTE 中继能够放置于 不同的地理位置, 使用商用或者预商用终端对中继部署的外场无线环境及性能进行试验, 对 TD-LTE 在外场部署的特点和性能研究具有重大的意义. 本文中对游牧中继在无线网络中的性能以及无线回 传信道进行了场外研究测试, 通过 TD-LTE 在外场测试中的性能分析对 TD-LTE 中继的现场部署给 出了位置及天线朝向等方面的建议, 本文研究中发现 TD-LTE 中继在非直视类型的回传链路环境下 对小区边缘的吞吐量仍然具有极大的提高.
\end{abstract}

关键词 TD-LTE 中继 游牧中继 非直视信道 回传链路 吞吐量 基站

\section{1 引言}

目前从 TD-LTE (time-division long-term evolution) 外场试验结果看, TD-LTE 提供了比以往 $2 \mathrm{G}$, 3G 系统更高的传输速率和更好的用户体验, 其服务场景包括传播环境复杂的密集城市、偏远郊区、室 内和高速覆盖等. 为了应对各种复杂的无线传播环境, 3GPP (3rd Generation Partnership Project) 在 版本 10 中对中继 (relay) 进行了标准化.

为了尽早研究中继在实际网络中的性能, 爱立信在 2010 年开发了基于 TD-LTE 的带内中继 ${ }^{[1]}$ 试 验系统, 其主要研究目的是 TD-LTE 中继的物理层技术 [2]、网络技术 ${ }^{[3]}$ 等在实现上的可行性 ${ }^{[4]}$. 为 了进一步研究中继在实际部署中的性能问题, 爱立信在 2011 年的中继试验系统二期开发设计了游牧 中继, 如图 1 所示, 重点研究中继在非直视路径的无线回传链环境中的性能和部署问题, 该问题的提 出是由于 TD-LTE 在功率谱密度上比 $3 \mathrm{G}$ 和 $2 \mathrm{G}$ 通信系统更低, 并且其采用了更高的载波频段, 所以 在密集城区的 TD-LTE 部署中往往存在传统普通宏基站难以覆盖的盲区. 若部署普通微蜂窝基站为 此类盲区提供覆盖, 则需要采用光纤或者微波作为回传链路, 光纤成本较高, 而在密集城区微蜂窝基站 和宏基站之间往往不存在直视路径, 无法采用微波回传链路. 如部署带内中继提供覆盖, 只要非直视 路径无线回传链路性能足够好, 上述两个问题将迎刃而解, 带内中继周期短成本低的优势凸显. 因此, 无线回传链路的性能成为 TD-LTE 中继的关键问题. 


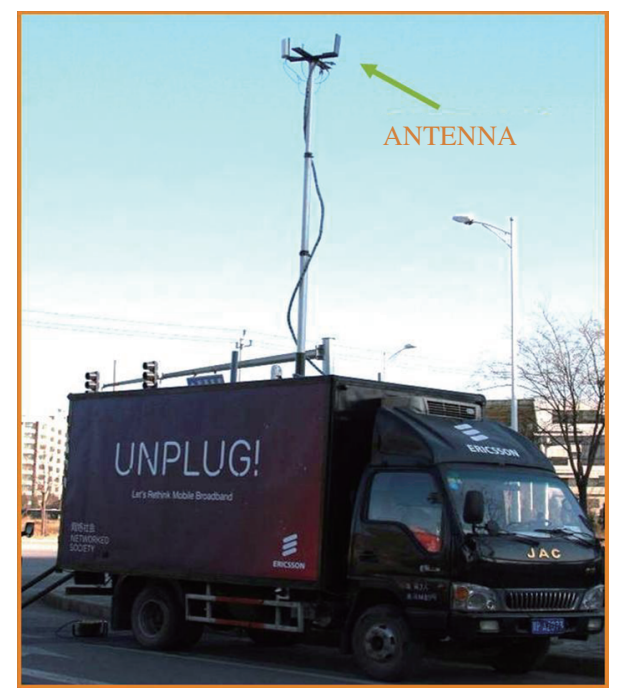

图 1 游牧中继

Figure 1 Nomadic relay

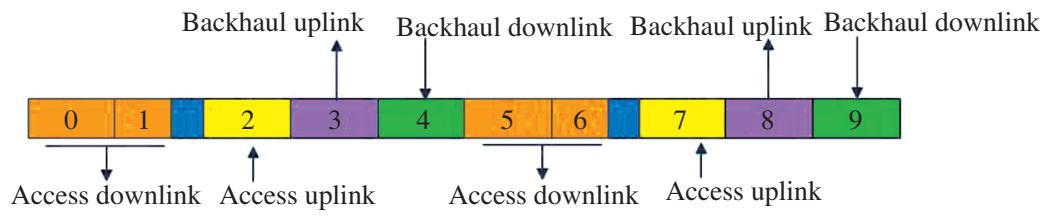

图 2 中继的时隙分配

Figure 2 Sub-frame allocation for backhaul and access link

\section{TD-LTE 游牧中继设计与开发}

该中继试验系统工作在 TDD 配置 1 下 (上下行配比 3:2), 属于 3GPP 定义的带内中继. 如图 2 所示, 在一个 $10 \mathrm{~ms}$ 的无线帧中, 4 个下行子帧 $(0,1,5,6)$ 和 2 个上行子帧 $(2,7)$ 分配给接入链路. 剩 下的 2 个下行子帧 $(4,9)$ 和 2 个上行子帧 $(3,8)$ 分配给回传链路. 为了保持对 LTE 版本 8 用户的后 向兼容, 子帧 4 和 9 在中继小区中被配置为 MBSFN (multicast broadcast single frequency network) 子 帧, 这样中继在子帧 4 和 9 的广播部分可以不向终端发任何信号, 但第一个 OFDM 符号的控制和导 频需要发送. 在该配置下, 下行采用两流传输时, 端到端的无丢包吞吐量可达到 $25.5 \mathrm{Mbps}$, 上行端到 端的无丢包吞吐量可达到 $8.77 \mathrm{Mbps}$. 如图 2 和 3 所示, 其中图 3 中不同链路的颜色与图 2 中不同子 帧的颜色相对应.

所谓 “TD-LTE 游牧中继” 是将中继无线回传和中继 eNB 的射频置于较近距离并放置于试验车, 游牧中继的天线高度可调, 在部署上具有较大的灵活性, 可方便进行各种中继部署的无线环境研究及 技术性能试验, 如外场中继应用的典型场景之一: 中继部署于街边路灯柱, 爱立信的游牧中继为该应用 场景中的中继性能研究提供了相当大的便利性, 通过改变中继位置和天线高度, 可以迅速获得不同无 线传播环境中不同高度的路灯柱中继的性能.

此外, 爱立信将中继的无线回传和中继的 eNB 射频置于较近的距离, 可以模拟 “一体化” 的中继 产品形态, 甚至模拟无线回传链路和中继 eNB 共天线作为中继的产品形态, 游牧中继这种接近于 “一 体化” 中继产品形态的特性, 有助于为未来 “一体化” 中继产品的部署和性能给出建议和研究分析. 


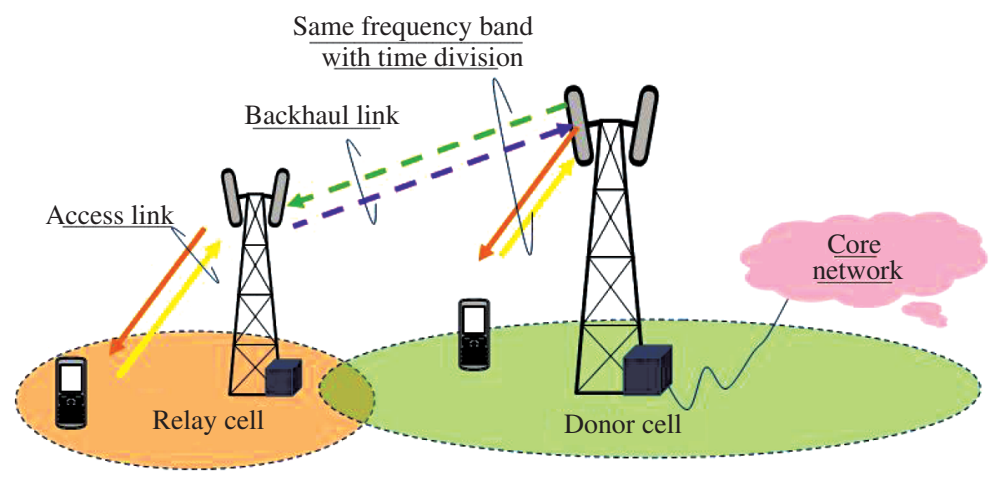

图 3 TD-LTE 中继的回传与宏基站覆盖和宏基站覆盖的链路示意图

Figure 3 Illustration of coverage for backhaul/donor and relay

在游牧中继试验系统开发中, 爱立信充分利用了 TDD 系统接收发送在同一频点采用同一射频通 道的特点, 采用了 $\mathrm{eNB}$ 的硬件平台加载中继的软件实现中继的方案, 但同时在中继的设计中, 需要考 虑到 eNB 平台的特殊性在游牧中继设计中的影响. 将中继的无线回传和中继的 eNB 射频置于较近的 距离在开发实现上的挑战性在于避免两者之间的干扰, 即在某一方接收信号时应将另一方的功率放大 器置于关闭的状态, 因为在功率放大器工作状态下其最小的噪声功率输出也会对近距离的设备产生较 大的干扰. 因此在中继试验系统设计中采用了快速的功率放大器控制, 保证了两者之间不会产生相互 干扰.

\section{3 外场技术试验}

外场技术试验包括无线回传链路信道测量试验和中继小区内用户的吞吐量的性能测试. 测试设备 配置包括位于图 4 右上角建筑物房顶的 8 天线 TD-LTE 宏基站和游牧中继. 其中宏基站下行每天线 最大功率为 $5 \mathrm{~W}$, 最大总功率为 $40 \mathrm{~W}$, 其广播波束指向如图 4 中所示.

\section{1 无线回传链路信道测量和试验}

在无线回传链路信道测量试验中, 中继放置于地理上的不同位置, 如图 4 所示, 其测试地理位置 分为 4 类. 区域 $A$ 距离宏基站约 $340 \mathrm{~m}$, 在中继和宏基站之间有约 $16 \mathrm{~m}$ 高的一座不规则建筑, 在中 继的背后有约 $23 \mathrm{~m}$ 高的建筑物. 区域 $B$ 距离宏基站约 $430 \mathrm{~m}$ 中继前方为规整的 $12 \sim 13 \mathrm{~m}$ 高遮挡建 筑, 在中继背后为约 $20 \mathrm{~m}$ 建筑. 区域 $C$ 距离宏基站约为 $650 \mathrm{~m}$, 在中继和宏基站之间为一座 $25 \mathrm{~m}$ 高 的阻挡建筑, 该区域中有多个反射建筑物. 区域 $D$ 距离宏基站约 $450 \mathrm{~m}$, 该区域较近处为遮挡建筑物, 但没有较近的反射建筑物. 测试中中继天线采用 $3 \mathrm{~dB}$ 波束宽度为 $90^{\circ}$ 的定向天线, 置于不同的高度 并可以 $360^{\circ}$ 水平方向旋转以接收不同方向上的来波信号. (注: 前方为中继朝向宏基站的方向, 后方为 中继背向宏基站的方向).

图 5 所示为测量结果, 图中的曲线为该测试点天线朝不同方向在高度为 $3,7,11 \mathrm{~m}$ 时所接收的 RSRP (reference signal received power) 强度. 图中可以看出当天线置于不同的高度和方向时 RSRP 具 有较大的差别, 该差别与中继接收的信号路径相关.

结果分析可知, 区域 $A$ 具有较好的 RSRP 接收强度, 并且中继天线朝向宏基站和朝向背后反射建 筑物具有接近的 RSRP 接收强度; RSRP 的接收强度随着天线高度的增加有较大的上升. 区域 $B$ 中 


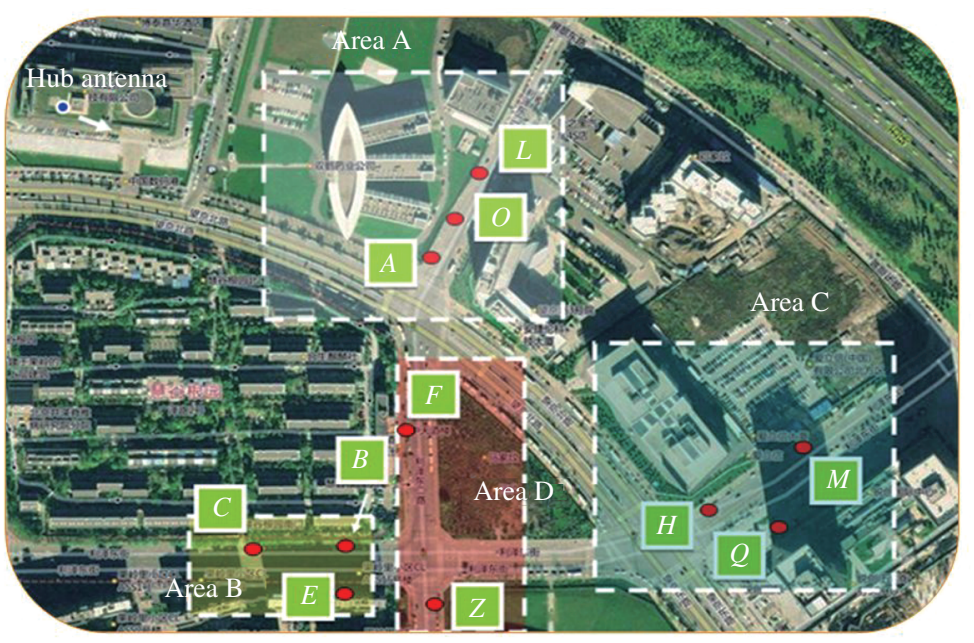

图 4 无线回传链路信道测量和试验地理环境

Figure 4 Measurement set up for wireless backhaul testing

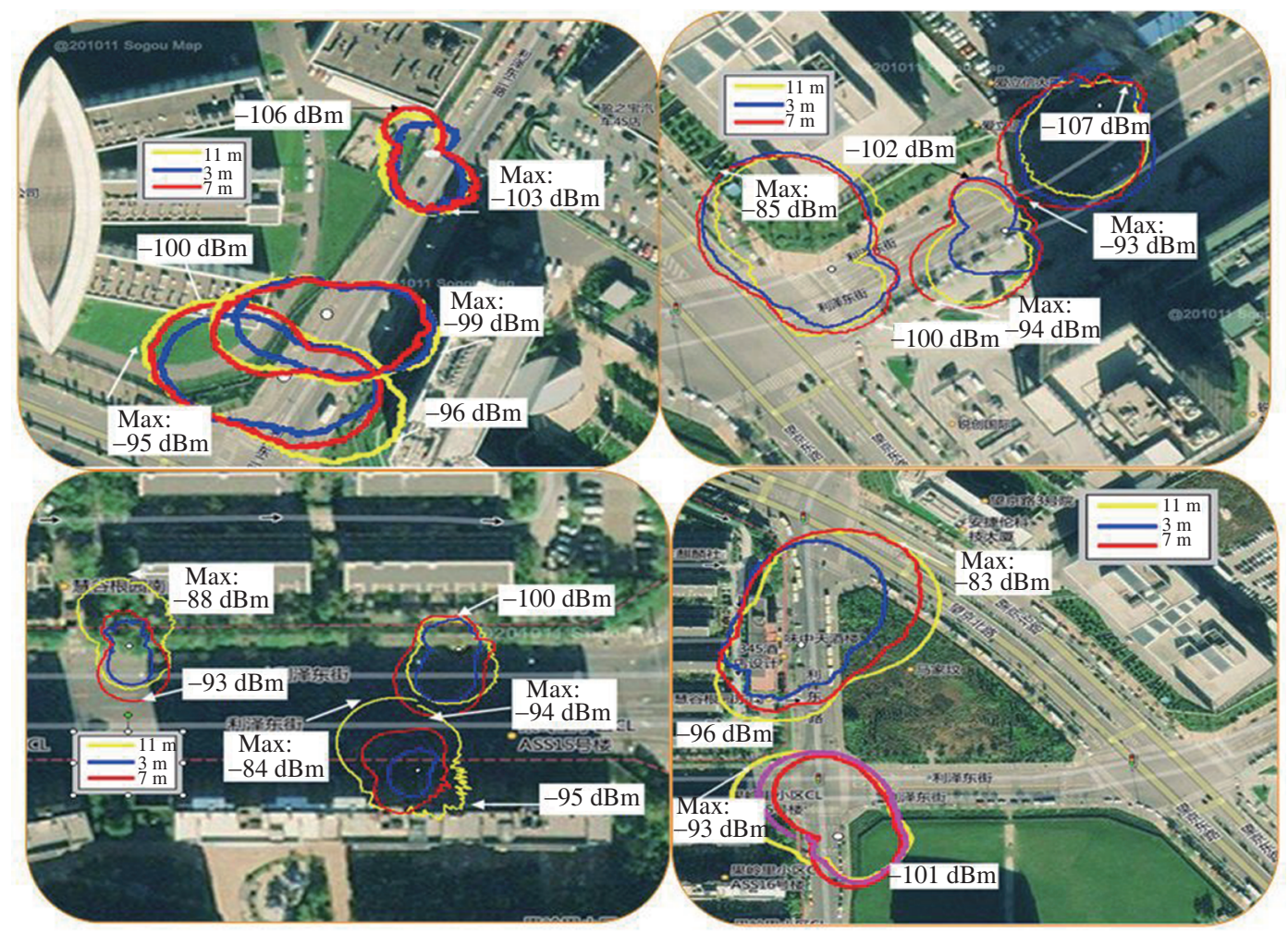

图 5 无线回传链路信道测量和试验结果

Figure 5 Wireless backhaul link channel measurement results

$E$ 点具有最好的 RSPR 强度, 分析认为它距离阻挡建筑物较远而在附近没有其他阻挡物, 因此带来较 小的绕射损耗. 对于 $C$ 区域, $H$ 点 RSRP 最大, 分析认为 $H$ 点所处位置与宏基站之间具有直视路径. $M$ 和 $Q$ 点上, 当天线朝向西南方向的反射建筑物时 RSRP 最高. 而 $D$ 区域中的点, 中继天线应该指 向远端反射建筑物或者朝向绕射物. 


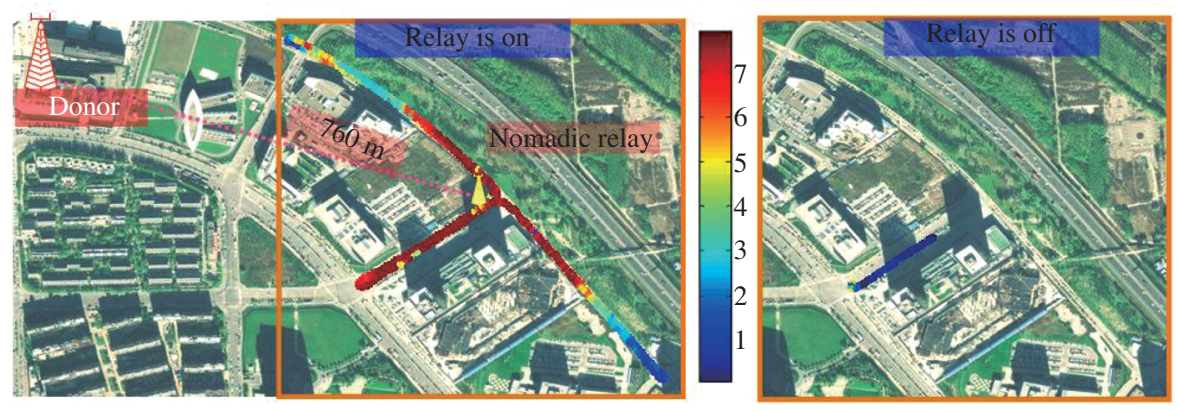

图 6 游牧中继打开与关闭时上行吞吐量的对比

Figure 6 Throughput coverage comparison of relay on and off

\section{2 点对点无线游牧中继的上行性能}

中继的 eNB 部分采用了室外型两天线基站, 其下行发送最大功率为 $2 \mathrm{~W}$, 天线采用距离较远的两 个柱状天线, 天线增益为 $2 \mathrm{dBi}$; 系统带宽为 $20 \mathrm{MHz}$ 支持 100 个物理资源块 (PRB: physical resource block); 宏基站与游牧中继之间距离约 $760 \mathrm{~m}$, 有 3 座建筑物阻挡. 测试终端为高通预商用终端. 游牧 中继的回传天线采用定向天线, 其 $3 \mathrm{~dB}$ 波束宽度为 $90^{\circ}$, 其指向为图 4 中的 $M$ 点 RSRP 最大接收方 向. 图 6 为中继打开和关闭时终端上行吞吐量的比较. 在中继关闭时, 测试路径中大部分没有宏基站 的覆盖, 只有少数路径点宏基站能够提供小于 $1 \mathrm{Mbps}$ 的吞吐量, 当中继打开在测试路径上能够提供 $7 \sim 8 \mathrm{Mbps}$ 的上行吞吐量.

结果表明, 在实际无线环境中的外场测试结果接近中继试验系统的设计目标. 部署 TD-LTE 中继 能在实际无线环境中扩展网络覆盖, 显著提高小区边缘用户的吞吐量.

\section{4 结论}

该文利用爱立信设计开发的 TD-LTE 游牧中继, 将其放置于具有不同无线信号传播特征的地理 位置, 进行了无线回传链路信道的测量, 并将游牧中继放置于小区边缘位置, 研究了中继对小区边缘吞 吐量的影响. 在无线回传链路测量中发现 TD-LTE 无线中继可以放置于绝大多数的小区边缘, 提供较 高的回传质量. 中继的回传天线应尽量放置于较高位置, 中继与宏基站之间没有直视路径的情况下回 传天线应避开近距离障碍物, 并指向中远距离的衍射物或者反射建筑物以获得较好的无线质量. 在小 区边缘位置能够极大地提升用户的吞吐量和用户体验, 扩展 TD-LTE 宏基站的覆盖范围.

\section{参考文献}

1 3GPP Organizational Partners (ARIB, ATIS, CCSA, ETSI, TTA, TTC). Further advancements for E-UTRA (physical layer aspects), 3GPP TR 36.814 V9.0.0, 2010

2 3GPP Organizational Partners (ARIB, ATIS, CCSA, ETSI, TTA, TTC). Physical Channels and Modulation, 3GPP TS 36.211 V9.1.0, 2010

3 3GPP Organizational Partners (ARIB, ATIS, CCSA, ETSI, TTA, TTC). Evolved Universal Terrestrial Radio Access Network (E-UTRAN) S1 Application Protocol (S1AP), 3GPP TS 36.413 V9.3.0, 2010

4 Gan J S, Guo Z H, Fan R, et al. LTE in-band relay prototype and field measurement. In: 2012 IEEE 75th Vehicular Technology Conference (VTC Spring), Yokohama, 2012. 1-5 


\title{
Design and field measurement of TD-LTE nomadic relay and backhaul
}

\author{
GUO ZhiHeng*, QIAN Yu, FAN Rui \& WANG Hai \\ Ericsson (China) Communications Company Ltd., Beijing 100102, China \\ *E-mail: zhiheng.guo@ericsson.com
}

\begin{abstract}
As a feature defined in Release 10 of 3GPP, TD-LTE relay has the ability to improve the cell edge throughput and expand coverage as well as to provide high speed wireless backhaul link. Ericsson as the technology leader in TD-LTE area built "TD-LTE nomadic in-band relay" prototype in 2011. For the prototype, the access link is totally compatible with the 3GPP TD-LTE Release 8 specification, which allows using commercial terminals for field measurement of the relay performance. The nomadic relay emulated the relay that the antennas for the relay $\mathrm{UE}$ and relay eNB are closely located which is one of the appearance of the relay product in the future where the relay could be plug-and-play. In this paper, wireless backhaul channel characteristics in various deployment scenarios and the throughput performance are measured when nomadic relay is deployed. It is found in the measurements that when the relay UE antenna is directional antenna, the direction of the antenna should be to the large reflections or diffractions. Relay can greatly improve the throughput in NLOS backhaul scenario in poor coverage area from the donor and provide coverage extension for the non-coverage area. The TD-LTE nomadic relay could be placed at most of the area of the cell edge of the donor cell with moderate backhaul link performance.
\end{abstract}

Keywords TD-LTE, relay, nomadic relay, NLOS channel, backhaul link, throughput, base station

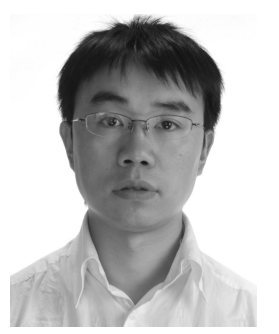

GUO ZhiHeng was born in 1979 He received his Ph.D. degree in circuit and system from Beijing University of Posts and Telecommunications in 2007. Currently he is working in Ericsson (China) Communication Company as a Senior Research Engineer. His research interests include wireless communication network.

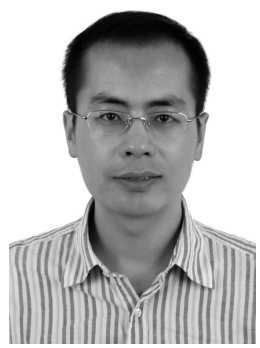

FAN Rui received his Ph.D. degree from Beijing University of Posts and Telecommunications in 2003. Currently he is a Senior Researcher in Ericsson Research Beijing Branch. His research area focus on L23 issues in WCDMA and LTE mobile network.

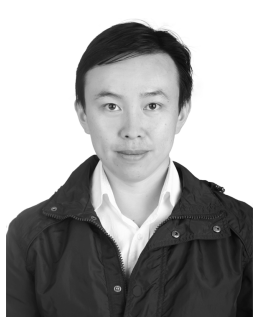

QIAN Yu was born in 1979. He received his B.S. degree in electronic engineering and Ph.D. degree in signal and information processing from Beijing University of Posts and Telecommunications in 2002 and 2007. Currently he is working in Ericsson (China) Communication Company as a Senior Research Engineer. His research interests include wireless communication network.

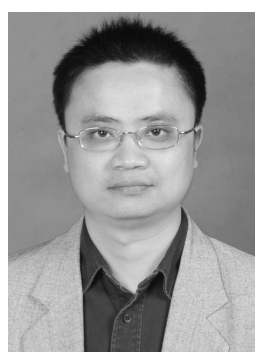

WANG Hai received his Ph.D. degree from Beijing University of Posts and Telecommunications in 1997. Currently he is the Head of China Radio Research Laboratory of Ericsson in Beijing. His research and interest area focus on L1/L23 issues in WCDMA and LTE mobile networks. 